\title{
The genus Cookeina
}

\author{
Ekanayaka AH', Hyde KD ${ }^{1,2}$, Zhao $Q^{1 *}$ \\ ${ }^{1}$ Key Laboratory for Plant Diversity and Biogeography of East Asia, Kunming Institute of Botany, Chinese Academy of \\ Sciences, Kunming 650201, Yunnan, China \\ ${ }^{2}$ Center of Excellence in Fungal Research, Mae Fah Luang University, Chiang Rai 57100, Thailand. \\ "Corresponding author e mail: zhaoqi@ mail.kib.ac.cn
}

Ekanayaka AH, Hyde KD, Zhao Q 2016 - The genus Cookeina. Mycosphere 7 (9), 1399-1413, Doi 10.5943/mycosphere/7/9/13

\begin{abstract}
Cookeina (Sarcoscyphaceae) is characterized by large, brightly coloured, stipitate apothecia and eccentrically, operculate asci. This paper provides detailed morphological descriptions of the sexual morphs of all the recorded species within the genus, including a new species, Cookeina garethjonesii. Phylogenetic analyses inferred from ITS sequence data strongly support species lineages with corresponding morphological differences.
\end{abstract}

Key words - apothecia - discomycetes - operculate - phylogeny - taxonomy

\section{Introduction}

The genus Cookeina Kuntze is an operculate discomycete genus of Pezizomycetes, typified by Cookeina tricholoma (Mont.) Kuntze. Several species been added to the genus (Seaver 1913, Denison 1967, Rifai 1968, Pfister \& Kaushal 1984). The salient characteristics of this genus are the large, brightly coloured, stipitate apothecia and fasciculate excipular hairs. Paraphyses are branched and anastomose freely at the apex to develop excipulum, asci are cylindrical with tapering bases and an eccentrically placed operculum at the apex, and ascospores are ellipsoid to fusiform and hyaline to subhyaline with longitudinal ribs (Bi et al. 1993, Denison 1967, Iturriaga \& Pfister 2006). Species of Cookeina are widespread, especially in tropical and subtropical regions (Hanlin 1998, Weinstein el al. 2002, Douanla-Meli \& Langer 2005, Iturriaga \& Pfister 2006). They are saprobes on dead plant material or on soil (Douanla-Meli \& Langer 2005; Iturriaga \& Pfister 2006).

The most recent comprehensive account of this genus is by Iturriaga and Pfister (2006). Since this study, several new species have been introduced and others have been synonymized. Although Index Fungorum (2016) lists 25 epithets, only 12 species, plus the new species introduced in this paper should be accepted (Weinstein et al. 2002, Iturriaga \& Pfister 2006). In the present study, the morphological characteristics and phylogenetic placements of all accepted Cookeina species based on ITS sequence data are given. A new species is described herein as Cookeina garethjonesii and compared with allied taxa to support its taxonomic placement.

\section{Materials \& Methods}

Sample collection specimen examination and deposition 
Four specimens of Cookeina were collected from Yunnan Province, southern China and southern Thailand in 2014 to 2015. Macroscopic and microscopic characters of the specimens were recorded. A Motic SMZ-168 stereo microscope was used to observe the structures of the apothecia. Sections of apothecia were made with a razor blade and mounted in water. A Nikon ECLIPSE 80i compound microscope was used to observe microscopic characters. Photomicrography was carried out with a Canon 450D digital camera fitted to the microscope. Measurements of paraphyses, asci and ascospores were made from materials mounted in water and the mean values were used in the descriptions. Measurements were made with the Taro soft $(\mathrm{R})$ Image Frame Work v. 0.9.7 program and images used for figures were processed with Adobe Photoshop CS6 software (Adobe Systems Inc.). The type specimens are deposited in the Mae Fah Luang University Herbarium (MFLU), Chiang Rai, Thailand and in the Herbarium of Cryptogams of Kunming Institute of Botany, Chinese Academy of Sciences (KUN-HKAS). Facesoffungi and Index Fungorum numbers were registered as described in Jayasiri et al. (2015) and Index Fungorum (2016).

\section{DNA extraction, PCR and sequencing}

Genomic DNA was extracted directly from the apothecia using a Plant DNA Rapid Extraction Kit (Bio Teke corperation, Beijing, China). Polymerase chain reactions (PCR) for this study were carried out for the internal transcribed spacer (ITS), using ITS4 and ITS5 (White et al. 1990) primers. The PCR mixtures $(25 \mu \mathrm{L})$ contained $\mathrm{ddH}_{2} \mathrm{O}(11 \mu \mathrm{L})$, PCR Master Mix (QinKe Co., China) $(11 \mu \mathrm{L} ; 2 \times)$, DNA template $(1 \mu \mathrm{L})$, each primer $(1 \mu \mathrm{L} ; 10 \mu \mathrm{M})$. PCR amplification conditions were consisted an initial denaturation step of $5 \mathrm{~min}$ at $94{ }^{\circ} \mathrm{C}, 35$ cycles consisted of denaturation at $94{ }^{\circ} \mathrm{C}$ for 1 minute, annealing at $53{ }^{\circ} \mathrm{C}$ for 50 seconds and elongation at $72{ }^{\circ} \mathrm{C}$ for 3 minute and final extension step of 7 minutes at $72{ }^{\circ} \mathrm{C}$. The PCR products were viewed on $1 \%$ agarose electrophoresis gels, stained with ethidium bromide. PCR products were sent to a commercial sequencing provider, Qinke in Kunming, China.

\section{Sequence alignment and phylogenetic analysis}

Newly generated sequences in this study were subjected to a standard BLAST search of GenBank for rough identification. Eighteen sequences belonging to ITS gene regions from representative Cookeina species and the out-group taxon Microstoma floccosum (Schwein.) Raitv., were downloaded from GenBank (Table 1). The newly generated sequences are deposited in

GenBank (Table 1) and alignment in Treebase under number S20159 (http://purl.org/phylo/treebase/phylows/study/TB2:S20159). The consensus sequences for each gene were aligned using MAFFT v. 6.864b (http://mafft.cbrc.jp/alignment/server/index.html). The alignment was improved manually where necessary using Bioedit (Hall 1999). The model of evolution was estimated by using MrModeltest 2.2 (Nylander 2004). Maximum likelihood phylogenetic analyses were performed in the CIPRES web portal (Miller et al. 2009) using RAxML-HPC2 Workflow on XSEDE (8.2.9) tool (Stamatakis 2006). The bootstrap analysis for each ML tree was performed with 1000 thorough bootstrap replicates with the same parameter settings using the GTR+ G substitution model selected by MrModel Test. Maximum parsimony analysis (MP) was performed with PAUP (Phylogenetic Analysis Using Parsimony) v. 4.0b10 (Swofford 2003) for the ITS gene region. Ambiguously aligned regions were excluded from the analyses; gaps were treated as missing data. Trees were inferred using the heuristic search option with TBR branch swapping and 1000 random sequence additions. Branches of zero length were collapsed and all equally most parsimonious trees were saved. Descriptive tree statistics such as tree length $[\mathrm{TL}]$, consistency index $[\mathrm{CI}]$, retention index [RI], rescaled consistency index [RC], and homoplasy index $[\mathrm{HI}]$, were calculated. The resultant trees were viewed with FigTree v.1.4.0 (http://tree.bio.ed.ac.uk/software/figtree/). Maximum likelihood bootstrap values equal or greater than $60 \%$ are given as the first set of numbers above the nodes and Maximum-parsimony bootstrap values equal or greater than $60 \%$ are given as the second set of numbers above the nodes (Fig. 1).

\section{Results}




\section{Phylogenetic analyses}

The ITS, dataset of representative species of Cookeina 719 characters (including alignment gaps) for 23 ingroup and one outgroup taxa. Of the 719 characters 358 were constant, 89 were variable and parsimony uninformative. Maximum parsimony analysis of the remaining 272 parsimony-informative characters resulted in 750 most parsimonious trees ( $\mathrm{TL}=750 ; \mathrm{CI}=0.717$, $\mathrm{RI}=0.833, \mathrm{RC}=0.597, \mathrm{HI}=0.283$ ) and the best tree is shown in Fig 1. Resultant tree shows four main clades (Fig. 1). The first clade includes our new species and that is phylogenetically close to Cookeina sulcipes.

Table 1 Taxa used in the phylogenetic analyses and ITS GenBank accession numbers.

\begin{tabular}{ccc}
\hline Species name & Strain number & ITS \\
\hline Cookeina colensoi & C.col118 & AF394532 \\
Cookeina colensoi & C.col121 & AF394531 \\
Cookeina cremeirosea & AS142 & KU306963 \\
Cookeina cremeirosea & AS210 & KU306964 \\
Cookeina garethonesii & HKAS90509 & KY094617 \\
Cookeina garethjonesii & HKAS90513 & KY094622 \\
Cookeina indica & C.ind119 & AF394029 \\
Cookeina indica & MFLU 16-0610 & KY094621 \\
Cookeina insititia & C.ins126 & AF394033 \\
Cookeina insititia & C.ins125 & AF394032 \\
Cookeina korfii & CUP SA-2454 & NR_136141 \\
Cookeina korfii & CUP-SA-1797 & KT893782 \\
Cookeina sinensis & C.sin111 & AF394028 \\
Cookeina sinensis & C.sin48 & AF394027 \\
Cookeina speciosa & C.spe6035 & AF394018 \\
Cookeina speciosa & C.spe31 & AF394017 \\
Cookeina sulcipes & isolate 2 & AF529292 \\
Cookeina sulcipes & isolate 1 & AF529291 \\
Cookeina sulcipes & MFLU 15-2358 & KY094620 \\
Cookeina tricholoma & MFLU 15-2359 & KY094618 \\
Cookeina tricholoma & HKAS87041 & KY094619 \\
Cookeina venezuelae & C.ven43 & AF394044 \\
Cookeina venezuelae & C.ven42 & AF394043 \\
Microstoma floccosum & Micro45 & AF394046 \\
\hline Newly generated sequences are in bold & \\
\hline
\end{tabular}

\section{Taxonomy}

Cookeina colensoiopsis Iturr. \& Pfister, Mycotaxon 95: 151 (2006)

Facesoffungi number: FoF 02666

Saprobic on dead stems. Sexual morph: Apothecia $20 \times 2-15 \mathrm{~mm}$ when fresh, and 14-15 $\times$ 1-8 mm when dry, scattered, centrally stipitate, deeply cupulate, bright yellow to orange when fresh, furfuraceous with white hair-like projections. Stipe 3-13 $\times 1-3 \mathrm{~mm}$ cream-colored, subcylindrical, wider at the base. Receptacle concave, bright yellow when fresh. Margins concolorous to receptacle. Disc darker than receptacle, bright yellow to orange when fresh, ochre when dry and orange when rehydrated. Ectal excipulum 30-90 $\mu \mathrm{m}$ composed of cells of textura globulosa to prismatica (8-14 $\mu \mathrm{m}$ diam.), 4-5 cell layers present. Medullary excipulum has two layers, outer layer 50-100 $\mu \mathrm{m}$ wide, composed of thin-walled cells of textura oblita $(2-1 \mu \mathrm{m}$ diam.), hypha immersed in a gel and oriented outwards, perpendicular to the receptacle surface, inner layer $60-600 \mu \mathrm{m}$ composed of long cells of textura porrecta $(4-6 \mu \mathrm{m})$. Subhymenium composed of gelatinized cells of textura intricata. Hymenium 380-450 $\mu \mathrm{m}$, hymenial setae present, $430-440 \times 2 \mu \mathrm{m}$, intermixed with asci and paraphyses, brownish with lanceolate terminal cell, exceeding hymenial elements by $10-20 \mu \mathrm{m}$. Paraphyses $2-4 \mu \mathrm{m}$ wide, numerous, filiform, septate, highly branched and slightly swollen to clavate at the apex forming the epithecium. Asci $340-420 \times$ 


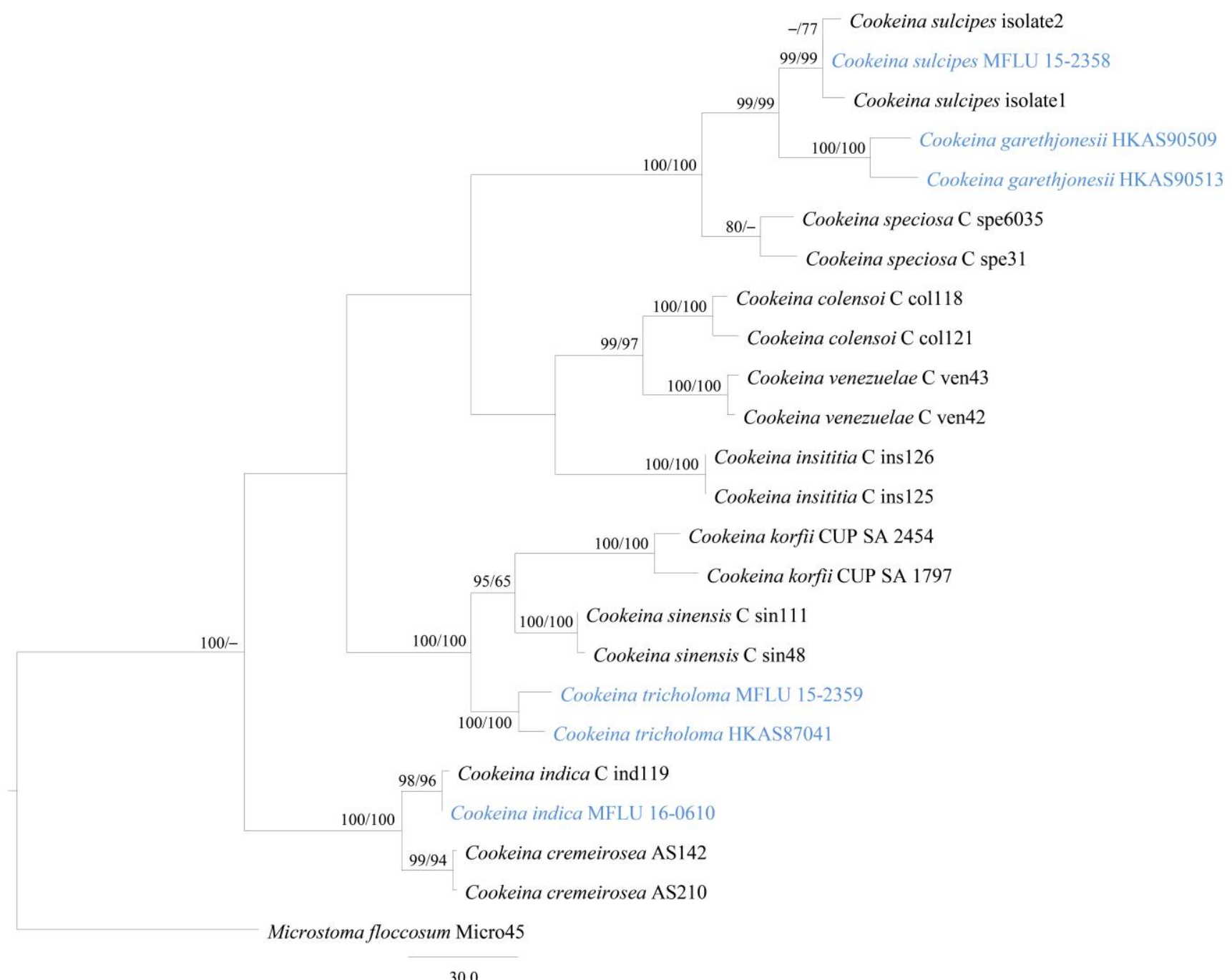

Fig. 1 - Phylogram generated from maximum parsimony analysis of sequences of Cookeina based on ITS sequence data. Maximum likelihood bootstrap values $\geq 60 \%$ are given as the first set of numbers and Maximum-parsimony bootstrap values $\geq 60 \%$ are given as the second set of numbers, above the nodes. Strain/culture numbers are given after the taxon names. The newly generated sequences are in blue. The tree was rooted with Microstoma floccosum (Micro45).

10-20 $\mu \mathrm{m}$, long, cylindrical with rounded base, ending in an abrupt manner to connect with hyphallike basal appendage, a few times tapering slightly at base, basal appendage 4-28 $\times 4 \mu \mathrm{m}$. Ascospores 30-34 × 12-14 $\mu \mathrm{m}$, obliquely uniseriate, broad elliptic, unequally sided, narrowing slightly at the ends, with a short apiculum present at both ends, mostly with two large central oil guttules with two smaller guttules at the ends, hyaline, smooth-walled. Asexual morph: Undetermined (description modified from Iturriaga \& Pfister 2006).

Notes - Cookeina colensoiopsis is similar to $C$. colensoi in the presence of hair-like appendages and smooth-walled ascospores, but differs in having long stipes and hymenial setae. A similar type of setae also has been observed only in C. speciosa (Iturriaga \& Pfister 2006).

Cookeina colensoi (Berk.) Seaver, Mycologia 5(4): 191 (1913)

Facesoffungi number: FoF 02667

Saprobic on dead wood. Sexual morph: Apothecia 1-1.5 $\times 0.5 \mathrm{~cm}$ arising singly, substipitate to stipitate, deep or shallow cupulate, brownish yellow to brownish orange when fresh, pale-yellow when dry, glabrous, gelatinous layer present, wrinkled when dry especially near the base of the cup. Stipe $<1 \mathrm{~mm}$. Receptacle concave, margins are covered with rudimentary hairs. Ectal excipulum $40 \mu \mathrm{m}(10-60 \mu \mathrm{m})$ outer cells composed of cells of textura globulosa, inner cells 
composed of gelatinized cells of textura angularis. Medullary excipulum composed of hyaline cells of textura intricata. Paraphyses numerous, filiform, highly branched and slightly enlarged at the apex producing epithecium. Asci 310-475 × 18-20 $\mu \mathrm{m}$ unitunicate, operculate, cylindrical, gradually tapering below. Ascospore 28-40 $\times 11-15 \mu \mathrm{m}$, uniseriate or with the ends slightly overlapping, narrowly ellipsoid or fusoid with the ends quite strongly narrowed, smooth, thinwalled, with one or two unequal large oil droplets and granular within, striations consisting of several broad, longitudinal bands extending the length of the spore. Asexual morph: Undetermined (description modified from Iturriaga \& Pfister 2006).

Notes - Both $C$. colensoi and $C$. venezuelae have gelatinized ectal excipular layer, but they are differ from spore ornamentation. Cookeina colensoi differ from $C$. insititia by ascospore shape (Douanla-Meli \& Langer 2005).

\section{Cookeina cremeirosea Kropp Mycoscience (in press) (2016)}

Facesoffungi number: FoF 02668

Saprobic on dead stems. Sexual morph: Apothecia 1-7 $\times 8 \mathrm{~mm}$ arising singly, centrallystipitate, deeply cupulate, pink when fresh, reddish yellow when dry. Receptacle concave, disc and margins are pink when fresh, minutely granular surface. Stipe $1 \mathrm{~mm}$ wide, central with a narrow attachment, somewhat compressed and fluted, concolorous with the receptacle but somewhat lighter towards the base. Hairs $60-100 \mu \mathrm{m}$ long. Hymenium pinkish orange, fading to pale-yellow in dried specimens. Ectal excipulum 35-70 $\mu \mathrm{m}$ composed of nongelatinized cells of textura angularis to textura globulosa. Medullary excipulum 120-228 $\mu \mathrm{m}$ composed of nongelatinized cells of textura porrecta. Paraphyses 2-4 $\mu \mathrm{m}$ wide, hyaline, septate, highly branched at the apex producing epithecium. Asci 324-336 $\times 14-17 \mu \mathrm{m}$ unitunicate, rounded at the base, cylindrical, nonamyloid. Ascospore 8-12 $\times 23-33 \mu \mathrm{m}$, uniseriate, amerosporae, ovoid, ends slightly narrowed and subpapillate, hyaline, guttules variable, aseptate, smooth, thin walled. Asexual morph: Undetermined (description modified from Kropp 2016).

Notes - Cookeina cremeirosea differs from $C$. indica in having smooth-walled ascospores and pinkish apothecia (Kropp 2016).

Cookeina garethjonesii Ekanayaka, Q. Zhao \& K.D. Hyde, sp. nov. Index Fungorum number: IF552534

Facesoffungi number: FoF 02669

Etymology - The specific epithet garethjonesii refers to the significant contribution of Professor E.B. Gareth Jones made to mycology.

Holotype - HKAS90509

Saprobic on dead stems. Sexual morph: Apothecia 1-3 $12-5 \mathrm{~cm}$ when fresh, arising singly, stipitate, deep cupulate. Hymenium glabrous, bright yellow to orange when fresh. Receptacle concave, margins slightly curved, disc and margins are yellow to orange when fresh. Stipe 1-1.5 $\times$ $0.1-0.3 \mathrm{~cm}$ when fresh, slender, hollow, forming a disc-like holdfast at the base, paler than the receptacle. Hairs $53-70 \times 10-16 \mu \mathrm{m}(\bar{x}=58.8 \times 13.8 \mu \mathrm{m}, \mathrm{n}=30)$ length and the width at the apex, arranged around the margin as a single row, apical cell slightly swollen, straight, thin-walled, septate, hyaline to yellowish. Hymenium hyaline. Ectal excipulum 97-132 $\mu \mathrm{m}(\bar{x}=109.8 \mu \mathrm{m}, \mathrm{n}=$ 10) two layered, outer ectal exipulum composed of large, thick-walled, hyaline cells of textura globulosa, inner ectal exipulum composed of hyaline thin-walled cells of textura prismatica, hyphae in ectal excipulum arranged perpendicular to the receptacle surface. Medullary excipulum 112-250 $\mu \mathrm{m}(\bar{x}=177 \mu \mathrm{m}, \mathrm{n}=10)$ composed of hyaline cells of textura intricata, hyphae arranged parallel to receptacle surface. Paraphyses $2.2-3.6 \mu \mathrm{m}$ wide $(\bar{x}=3.3 \mu \mathrm{m}, \mathrm{n}=20)$, numerous, filiform, septate, highly branched and slightly swollen at the apex, forming the epithecium. Asci 280-310 $\times 18-23 \mu \mathrm{m}(\bar{x}=300 \times 21.3 \mu \mathrm{m}, \mathrm{n}=30)$, unitunicate, sub-operculate, cylindrical, short pedicellate, obtuse at the base, non-amyloid. Ascospores $26-30 \times 15-17 \mu \mathrm{m}(\bar{x}=28.7 \times 16.3 \mu \mathrm{m}$, $\mathrm{n}=40$ ), uniseriate, 1-celled, ovoid, ends obtuse, hyaline or subhyaline, with one or two large oildrops, aseptate, smooth-walled, thin-walled. Asexual morph: Undetermined. 
Material examined - CHINA, XSBN Tropical Botany Garden, Menla County, Yunnan Province, 540m alt., on soil near the vegetation of Quercus sp. 5 August 2015, Qi Zhao- 2635 (HKAS90509, holotype), same location, 5 August 2015, Qi Zhao2639 (HKAS90513, isotype).

Notes - Cookeina garethjonesii is similar to C. sulcipes in its deep cupulate apothecia and straight, thin-walled, short hairs. However, $C$. sulcipes have pinkish apothecia and ascospores with thick gelatinous sheath, while ascospores of $C$. garethjonesii lack a gelatinous sheath and produce yellowish apothecia. Cookeina garethjonesii differ from C. speciosa, C. colensoiopsis and C. globosa by not having hairs or setae in the hymenium (Iturriaga \& Pfister 2006).
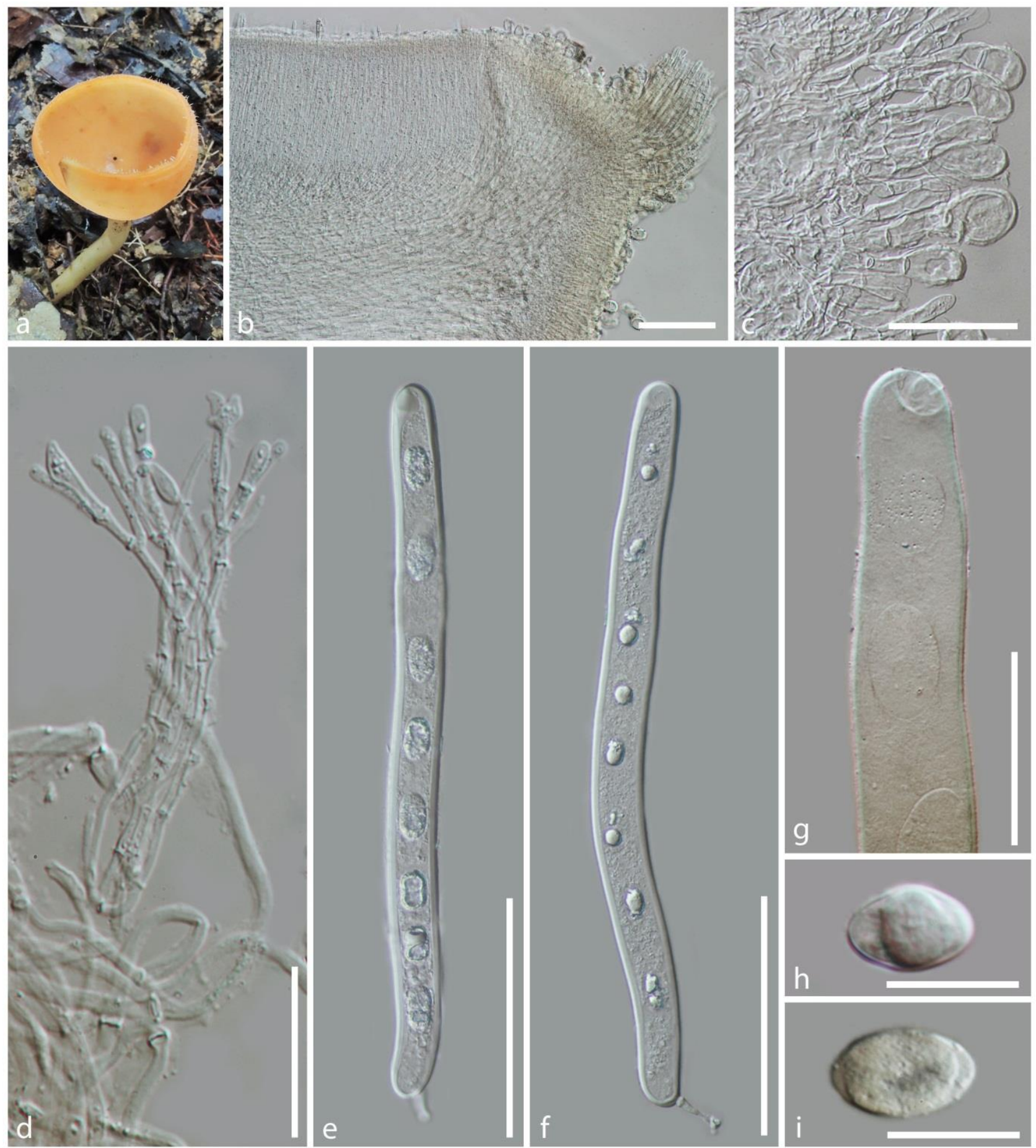

Fig. 2 - Cookeina garethjonesii (HKAS90509). a Apothecia on wood, b Cross section of an apothecium, c Cylindric, short hairs, d Septate, branched paraphyses, e-f Cylindrical asci, g Sub operculate apical apex (open state), $\mathrm{h}-\mathrm{i}$ Ovoid ascospores. - Scale bars $\mathrm{b}=100 \mu \mathrm{m}, \mathrm{c}=50 \mu \mathrm{m}, \mathrm{d}=$ $35 \mu \mathrm{m}, \mathrm{e}-\mathrm{f}=100 \mu \mathrm{m}, \mathrm{g}=50 \mu \mathrm{m}, \mathrm{h}-\mathrm{i}=25 \mu \mathrm{m}$. 
Cookeina globosa Douanla-Meli, Mycotaxon 92: 225 (2005)

Facesoffungi number: FoF 02670

Saprobic on dead stems. Sexual morph: Apothecia $8-20 \times 7-17 \mathrm{~mm}$ in diameter, gregarious, subsessile to short stipitate, deeply cupulate, pink to pale lead when fresh and brownish-yellow when dry. Receptacle 4-12 mm deep, concave, fertile surface smooth, shiny, lower sterile surface glabrous to finely velvet. Margin entire, erect but slightly incurved when dry. Stipe 3-5 mm long, cylindrical, often curved, composed of pale orange cells of textura porrecta (up to $5 \mu \mathrm{m}$ diam), hyaline, simple septate, nearly thick-walled. Hairs $1 \mathrm{~mm}$ long on flanks and margins, cylindrical, straight, white. Ectal excipulum 60-100 $\mu \mathrm{m}$ thick, composed of cells of textura angularis to globulosa, few layers of polygonal cells in gelatinous tissues, the outer cells globose, larger with thickened yellowish-brown walls, inner cells hyaline. Medullary excipulum composed of hyaline cells of textura intricata to porrecta, loosely interwoven hyphae, up to $6 \mu \mathrm{m}$ diameter. Subhymenium 10-25 $\mu \mathrm{m}$ thick, composed of cells of textura intricata. Hymenium pink, hymenial hairs present. Paraphyses 1-4 $\mu \mathrm{m}$ wide, numerous, filiform, highly branched and slightly swelled at the apex producing epithecium, protruding up to $45 \mu \mathrm{m}$ above the asci level. Asci 300-370 $\times 13-$ $20 \mu \mathrm{m}$ unitunicate, thick-walled, cylindrical, slightly tapering at the base and usually contracted into a short narrow stalk, 8-spored, suboperculate with operculum arranged obliquely on ascus apex, non-amyloid. Ascospores 11-16 × 9-12 $\mu \mathrm{m}$, uniseriate, subglobose to globose, thin-walled, smooth, usually fined with two large and several small oil droplets. Asexual morph: Undetermined (description from Douanla-Meli \& Langer 2005).

Notes - Cookeina globosa is similar to C. colensoi in having glabrous, subsessile apothecia, but the $C$. colensoi differs in spore ornamentation and not having a gelatinized ectal excipular layer (Douanla-Meli \& Langer 2005).

Cookeina indica Pfister \& R. Kaushal, Mycotaxon 20(1): 117 (1984)

Fig. 3 Facesoffungi number: FoF 02671

Saprobic on dead stems. Sexual morph: Apothecia 1-3 $\times 4-8 \mathrm{~cm}$ arising singly or gregarious, stipitate, deep or more shallow cupulate, yellow to orange when fresh, stalk $220 \times 1.5$ mm. Receptacle concave. Disc yellow to orange when fresh, nearly smooth except at the margin where it is minutely furfuraceous. Margins entire, lighter in colour than disc. Hymenium yellow, smooth. Ectal excipulum 70-100 $\mu \mathrm{m}(\bar{x}=79.8 \mu \mathrm{m}, \mathrm{n}=10)$ composed of large, thin-walled, hyaline cells of textura prismatica to globulosa. Medullary excipulum $100-140 \mu \mathrm{m}(\bar{x}=117.9 \mu \mathrm{m}$, $\mathrm{n}=10)$, composed of hyaline cells of textura intricata. Paraphyses $2.5-4.5 \mu \mathrm{m}$ wide $(\bar{x}=3.3 \mu \mathrm{m}$, $\mathrm{n}=20$ ), numerous, filiform, septate, highly branched and slightly swollen at the apex forming the epithecium. Asci 420-520 $\times 24-30 \mu \mathrm{m}(\bar{x}=487.2 \times 27.1 \mu \mathrm{m}, \mathrm{n}=30)$, unitunicate, operculate, cylindrical, base narrow-hyphoid, short pedicellate, thick-walled, apices obtuse, non-amyloid. Ascospores 31-37 $\times 14-16 \mu \mathrm{m}(\bar{x}=33.6 \times 14.9 \mu \mathrm{m}, \mathrm{n}=40)$, uniseriate, 1-celled, ovoid, ends slightly narrow, often inequilateral, hyaline with 3 guttules or multiguttulate, aseptate, ornamentation of fine longitudinal, parallel ridges. Asexual morph: Undetermined (description modified from Iturriaga \& Pfister 2006).

Material examined - CHINA, Kunming, Yunnan Province, 4 December 2013, S.C. Karunarathna, NB036 (MFLU 16-0610).

Notes - Cookeina indica is distinct from other species of the genus in having striate spores with pointed apices, a yellow hymenium and a non-hairy, nearly smooth outer receptacle surface (Iturriaga \& Pfister 2006).

Cookeina insititia (Berk. \& M.A. Curtis) Kuntze, Revis. gen. pl. (Leipzig) 2: 849 (1891) Facesoffungi number: FoF 02672

Saprobic on dead stems. Sexual morph: Apothecia 4-11 $\times 9-25 \mathrm{~mm}$ tall when dry, arising singly to gregarious, centrally stipitate, deep cupulate, white to pale cream when fresh. Receptacle concave, urceolate to turbinate, white to pale cream, when dry beige or yellow-ochre. Disc darker than the receptacle. Margin concolorous to the receptacle. Hairs three types, all originated from 

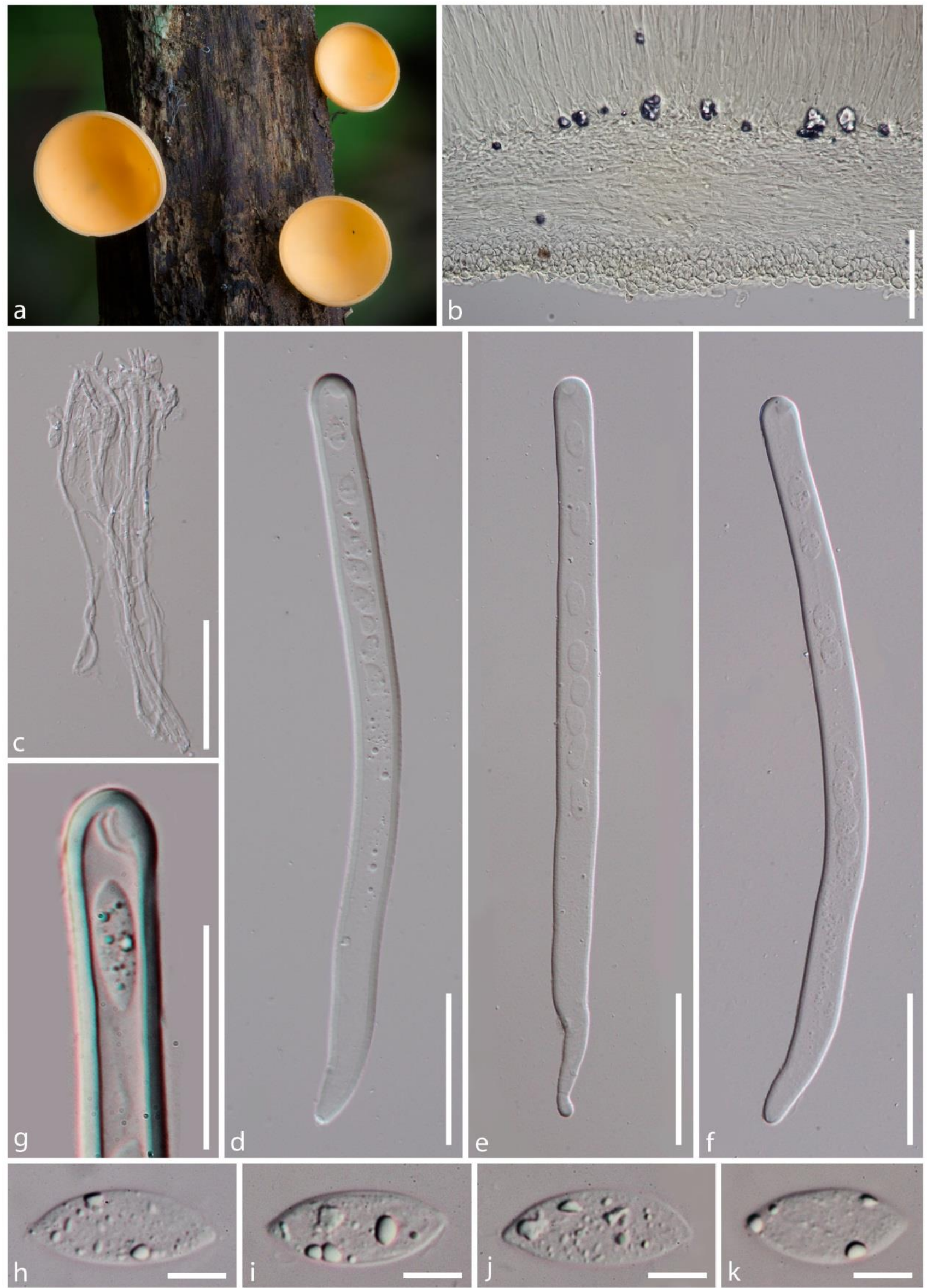

Fig. 3 - Cookeina indica. a Apothecia on wood, b Cross section of an apothecium, c Septate, branched paraphyses, d-f Cylindrical asci, g Sub operculate apical apex (closed state), h-k Ovoid ascospores. - Scale bars $\mathrm{b}=150 \mu \mathrm{m}, \mathrm{c}-\mathrm{f}=100 \mu \mathrm{m}, \mathrm{g}=50 \mu \mathrm{m}, \mathrm{h}-\mathrm{k}=10 \mu \mathrm{m}$. 
outer ectal excipulum 1) marginal twisted (when dry) hairs up to $2 \times 0.5 \mathrm{~mm}$, light yellow, triangular and flattened, in 1-2 rows, gradually tapered towards the apex, 2) hairs, straight, in the margin intermixed with the twisted hairs, covering mainly the upper part of the receptacle, half the size of the marginal ones, similar in structure to them, 3) hyphal projections covering receptacle and stipe. Stipe whitish, 3-16 × 1-2 $\mathrm{mm}$ when dry, up to $40 \mathrm{~mm}$ long when fresh, sometimes with a disc-shaped point of attachment. Ectal excipulum composed of two layers, outer ectal excipulum 30-50 $\mu \mathrm{m}$, composed of thick and sometimes warted-walled, hyaline cells of textura globulosa to angularis, inner ectal excipulum 20-80 $\mu \mathrm{m}$, composed of cells textura oblita, loosely interwoven, delicate, septate, branched, thin-walled hyphae immersed in a distinct gelatinous matrix and oriented perpendicular to the receptacle surface. Medullary excipulum composed of septate, typically unbranched cells of textura porrecta to intricata. Subhymenium composed of cells of textura intricata. Paraphyses 1-2 $\mu \mathrm{m}$ wide, filiform, septate, highly branched and slightly swollen at the apex forming an epithecium. Asci 400-453 × 12-16, $\mu \mathrm{m}$ unitunicate, operculate, cylindrical, tapering to a long thin obconical base. Ascospores 36-52 $\times 8-16 \mu \mathrm{m}$, uniseriate, narrow subfusoidal to fusoida1, asymmetrical or distinctly curved, with pointed ends, hyaline, smooth-walled, containing numerous guttules. Asexual morph: Undetermined (description modified from Iturriaga $\&$ Pfister 2006).

Notes - Cookeina insititia is distinct from other species of the genus in having three types of hairs. Meléndez-Howell et al. (2003) showed that although smooth-walled under the light microscope, ascospores have low convolute markings under the SEM. Moreover the ascus apex of C. insititia differs from other species by the absence of the $\mathrm{d} 2$ wall layer (Meléndez-Howell et al. 2003). The other unique characteristic of $C$. insititia is the presence of single ascospore wall layer (Boedjin 1933, Pfister 1973).

Cookeina korfii Iturr., F. Xu \& Pfister, Ascomycete.org 7(6): 331 (2015)

Facesoffungi number: FoF 02673

Saprobic on dead stems. Sexual morph: Apothecia $18 \times 35 \mathrm{~mm}$ when dry, arising singly or scattered, stipitate, deeply cupulate with an eccentric stipe, orange pigments exuded into water in dry specimens. Stipe 4-20 × 2.5-4 mm when dry, eccentric, concolorous with receptacle, subcylindrical, slightly wider at the base, with longitudinal ridges and furrows over its entire length when dry, the furrows, extending to the receptacle. Receptacle concave, light yellow to orange when dry, covered by uniformly distributed long, conspicuous hairs, sometimes pruinose surface. Disc paler than the receptacle when dry. Margin concolorous or lighter colored than the receptacle. Spines 3-7 mm long, wider at the base and tapering gradually towards the apex, composed of fascicles of parallel hyphae, on flanks and margins, thick-walled, septate, flexuous when rehydrated, though stiff when dry, white to whitish when rehydrated, to light-brown to brown when dry. Hairs shorter hyphae surrounding the base of the hairs, with rounded apices. Ectal excipulum 2 layers, outer ectal excipulum 46-65 $\mu \mathrm{m}$, composed of hyaline cells of textura globulosa, cells arranged perpendicularly to the surface of the receptacle, Inner ectal excipulum 88-125 $\mu \mathrm{m}$, composed of dense, thin-walled textura porrecta. Medullary excipulum 110-150 $\mu \mathrm{m}$ composed of hyaline cells of textura intricata. Subhymenium $30 \mu \mathrm{m}$, composed of textura intricata. Paraphyses 2-3 $\mu \mathrm{m}$ wide, numerous, filiform, septate, sometimes constricted at the septa, highly branched at the apex, forming the epithecium. Asci 230-255 $\times 9-11 \mu \mathrm{m}$, unitunicate, operculate, long, cylindrical, abruptly constricted and narrow-hyphoid at the base. Ascospores 18-25 $\times 9-11.5 \mu \mathrm{m}$, uniseriate, elliptic-fusoid to narrow, light yellow, aseptate, smooth, thin-walled, pointed at both poles, and with irregular to rounded apiculi frequently present at one or both poles, 0 (to 1) to 2guttulate. Asexual morph: Undetermined (description modified from Iturriaga et al. 2015).

Notes - Cookeina korfii is most similar to C. tricholoma and to $C$. sinensis, but differs in having smooth-walled, smaller and fusoid-apiculate ascospores (Iturriaga et al. 2015).

Cookeina sinensis Zheng Wang, Mycotaxon 62: 293 (1997)

Facesoffungi number: FoF 02674 
Saprobic on dead stems. Sexual morph: Apothecia up to $25 \times 50 \mathrm{~mm}$ when dry, arising singly and scattered, centrally stipitate, deeply cupulate, pink to orange when fresh. Stipe short, subcylindrical. Receptacle concave, pinkish orange, covered more or less uniformly with conspicuous long hairs. Margin somewhat in-rolled. Hairs 3-7 mm long 6-8 $\mu \mathrm{m}$ wide, on flanks and margins, fasciculate, stiff, bristle-like, white to brownish. Ectal excipulum about $50 \mu \mathrm{m}$, composed of thick-walled, hyaline cells of textura angularis. Medullary excipulum 230-300 $\mu$ m, composed of hyaline cells of textura intricata. Paraphyses 2.5-4 $\mu \mathrm{m}$ wide, moniliform, slender, septate, highly branched at the apex, forming the epithecium. Asci 275-350 × 15-20 $\mu \mathrm{m}$, unitunicate, suboperculate, cylindrical, narrow-hyphoid at base, thick-walled, non-amyloid. Ascospores $16 \times 34-40 \mu \mathrm{m}$, broad ellipsoid or subfusoid, pointed at both ends, pale yellow, smooth-walled, biguttulate. Asexual morph: Undetermined (description modified from Iturriaga \& Pfister 2006).

Notes - Cookeina sinensis is distinct from other species in having conspicuous hairs arising from medullary excipulum and moniliform paraphyses. Cookeina sinensis is similar to C. colensoi, $C$. sinensis and $C$. tricholoma in apothecial shape, structure and colour, but differs in apothecial size (up to $50 \mathrm{~mm}$ in diameter) and having smooth-walled ascospores. Both Cookeina sinensis and C. colensoi bear smooth-walled ascospores, but they differ by having a non-gelatinized ectal excipulum (Iturriaga \& Pfister 2006).

Cookeina speciosa (Fr.) Dennis, Mycotaxon 51: 239 (1994)

= Cookeina amoena, (Lév.) Kuntze, Revis. gen. pl. (Leipzig) 2: 849 (1891)

= Cookeina javanica (Nees \& Lév.) Kuntze, Revis. gen. pl. (Leipzig) 2: 849 (1891)

= Cookeina sumatrana Boedijn, J. Indian bot. Soc. 26: 407 (1929)

Facesoffungi number: FoF 02675

Saprobic on dead stems. Sexual morph: Apothecia 10-50 $\times 10-80 \mathrm{~mm}$, arising singly or gregarious, centrally stipitate, deep or more shallow cupulate or goblet-shaped. Receptacle concave, whitish. Stipe 3-75 × 1-6 mm slender, hollow, slightly attenuate below and often forming a disclike holdfast at the bottom, concolorous or even paler than the receptacle. Hairs up to $2 \mathrm{~mm}$ long, arranged around the margin as a single row, composed of bundles of septate and thick-walled hyphae. Ectal excipulum of two layers, outer ectal exipulum 28-80 $\mu \mathrm{m}$, composed of thick-walled, hyaline to light brown cells of textura globosa to angularis or prismatica, lying perpendicular to the surface of the receptacle, inner ectal excipulum 30-300 $\mu \mathrm{m}$ composed of cells of textura intricata, layer is gelatinized only in fertile young specimens, disappearing at maturity. Medullary excipulum composed of cells of textura intricata to porrecta. Subhymenium 15-30 $\mu \mathrm{m}$, composed of cells of textura intricata to porrecta, gelatinized in immature specimens. Hymenium surface smooth, yellow orange, grayish brown to pale chocolate-brown, highly hygrophanous, becoming upon drying uniformly concolorous, pastel yellow to brownish-yellow. Hymenial setae interspersed with asci and paraphyses, sometimes dark, tortuose, thick-walled, exceeding the hymenium by $22-$ $40 \mu \mathrm{m}$. Paraphyses $2-4 \mu \mathrm{m}$ wide, numerous, filiform, highly branched at the apex producing epithecium. Asci 300-370 × 17-19 $\mu \mathrm{m}$, unitunicate, operculate, cylindrical. Ascospores 22-33 $\times$ 10-16 $\mu \mathrm{m}$, ellipsoid, thick-walled, surface with longitudinal ridges, biguttulate. Asexual morph: undetermined (description modified from Iturriaga \& Pfister 2006).

Notes - Cookeina speciosa is distinct in having orange-yellow, orange to chocolate-brown apothecia (when fresh) and ascospores with a sinusoid surface ornamentation (Weinstein et al. 2002; Meléndez-Howell et al. 2003). Cookeina speciosa is similar to C. tricholoma, but differs in having evenly distributed hairs arising from medullar excipulum (Wang 1997). Both Cookeina speciosa and $C$. sinensis have hirsute apothecia, but they differ in ascospore ornamentation.

Cookeina sulcipes (Berk.) Kuntze, Revis. gen. pl. (Leipzig) 2: 849 (1891)

Fig. 4

= Cookeina hindsii (Berk.) Kuntze, Revis. gen. pl. (Leipzig) 2: 849 (1891)

Facesoffungi number: FoF 02676 


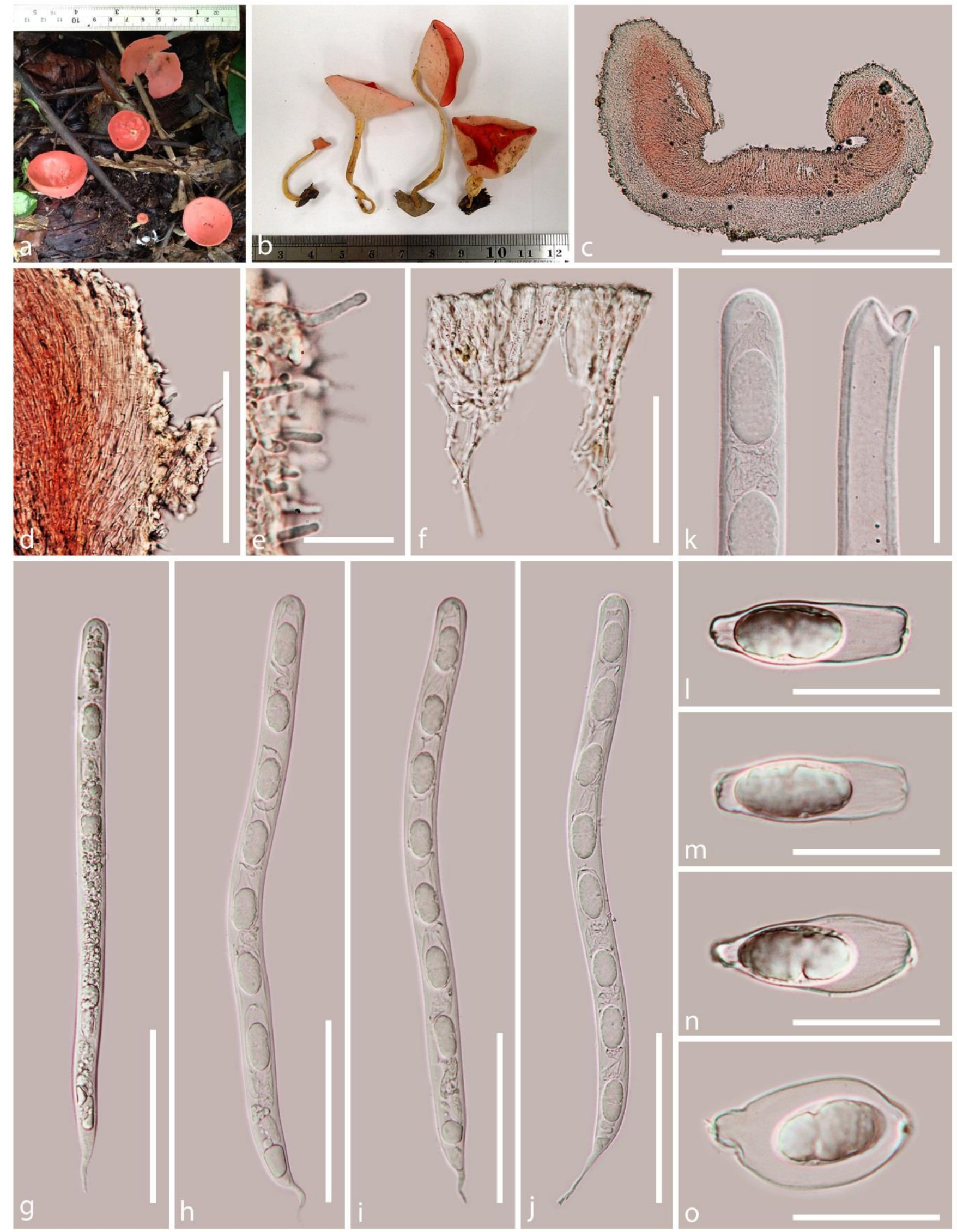

Fig. 4 - Cookeina sulcipes. a Apothecia on wood, b Apothecia, c Cross section of an apothecium, d Close up of excipulum at margins, e Cylindric, short hairs, f Septate, branched paraphyses, g-j long pedicellate asci, k Sub operculate apical apex (closed state in left and open state in right), 1-o Ovoid ascospores. - Scale bars $\mathrm{c}=1000 \mu \mathrm{m}, \mathrm{d}=100 \mu \mathrm{m}, \mathrm{e}=25 \mu \mathrm{m}, \mathrm{f}=70 \mu \mathrm{m}, \mathrm{g}-\mathrm{j}=100 \mu \mathrm{m}, \mathrm{k}=70 \mu \mathrm{m}$, $1-\mathrm{o}=30 \mu \mathrm{m}$. 
Saprobic on dead stems. Sexual morph: Apothecia $1-3 \times 4-8 \mathrm{~cm}(\bar{x}=2.2 \times 4.8 \mu \mathrm{m}, \mathrm{n}=10)$ arising singly, stipitate, deep or more shallow cupulate, pink to orange when fresh. Receptacle concave, disc and margins are pink to orange when fresh. Hairs $13-15 \times 2-3 \mu \mathrm{m}(\bar{x}=14.1 \times 2.7 \mu \mathrm{m}, \mathrm{n}=$ 30) on flanks and margins, cylindrical, straight, thin-walled, aseptate, hyaline undifferentiated hyphal tip. Stipe 0.5-3 mm long, lighter than the receptacle. Excipulum 120-200 $\mu \mathrm{m}(\bar{x}=166.2$ $\mu \mathrm{m}, \mathrm{n}=10$ ). Ectal excipulum composed of large, thin-walled, hyaline to pinkish cells of textura prismatica and medullary excipulum composed of hyaline to pinkish cells of textura intricata. Hymenium pinkish orange, fading to pale-yellow in dried specimens. Paraphyses 2.2-3.6 $\mu \mathrm{m}$ wide $(\bar{x}=3.3 \mu \mathrm{m}, \mathrm{n}=20$ ), numerous, filiform, septate, highly branched and slightly swollen at the apex forming the epithecium. Asci $280-380 \times 15-22 \mu \mathrm{m}(\bar{x}=339.2 \times 19.6 \mu \mathrm{m}, \mathrm{n}=30)$, unitunicate, operculate, cylindrical, short pedicellate, non-amyloid. Ascospores $21-30 \times 11-18 \mu \mathrm{m}(\bar{x}=24.8 \times$ $12.5 \mu \mathrm{m}, \mathrm{n}=40$ ), uniseriate, 1-celled, ovoid, ends slightly narrowed, hyaline or subhyaline with one or two large oil-drops, aseptate, smooth, thin-walled, with thick gelatinous sheath. Asexual morph: Undetermined (description modified from Seaver 1913; Patil et al. 2012).

Material examined - THAILAND, Prachuapkhirikhan Province, Pong Prasat, Bang Saphan District, July 30, 2015, A.R. Bandara (MFLU 15-2358).

Notes - Cookeina sulcipes differs from all the other species in the genus in having ascospores with thick gelatinous sheath (Iturriaga \& Pfister 2006, Patil et al. 2012).

Cookeina tricholoma (Mont.) Kuntze, Revis. gen. pl. (Leipzig) 2: 849 (1891)

Fig. 5

Facesoffungi number: FoF 02677

Saprobic on dead stems. Sexual morph: Apothecia $1-3 \times 4-8 \mathrm{~cm}(\bar{x}=2 \times 5.2 \mu \mathrm{m}, \mathrm{n}=10)$, arising singly, stipitate, deeply cupulate. Receptacle concave, glabrous, disc orange when fresh. Stipe 1-1.5cm long, 0.2-0.4cm broad, glabrous, lighter than the receptacle surface. Margin enrolled, concolorous to receptacle surface. Spines $2-7 \times 0.5-1 \mathrm{~mm}(\bar{x}=3 \times 0.8 \mu \mathrm{m}, \mathrm{n}=30)$ cylindrical, narrowed tips, aseptate. Hairs $70-80 \times 8-12 \mu \mathrm{m}(\bar{x}=73.5 \times 10.1 \mu \mathrm{m}, \mathrm{n}=30)$ on flanks and margins, cylindrical, straight, thin-walled, septate, hyaline. Hymenium orange to hyaline when fresh. Ectal excipulum two layers, outer ectal excipulum 10-100 $\mu \mathrm{m}$, composed of large, thin-walled, hyaline cells of textura globulosa, inner ectal excipulum 30-60 $\mu \mathrm{m}$, composed of thin-walled hyaline cells of textura intricata, hyphae oriented perpendicular to the receptacle surface. Medullary excipulum 160-200 $\mu \mathrm{m}$, composed of hyaline cells of textura intricata. Subhymenium 40-60 $\mu \mathrm{m}$ composed of loosely arranged hyaline cells of textura intricata. Paraphyses $2-4 \mu \mathrm{m}$ wide $(\bar{x}=3.5 \mu \mathrm{m}, \mathrm{n}=20$ ), numerous, filiform, septate, highly branched and slightly swollen at the apex, forming the epithecium. Asci $220-320 \times 8-22 \mu \mathrm{m}(\bar{x}=264.4 \times 13.5 \mu \mathrm{m}, \mathrm{n}=30)$ unitunicate, operculate, cylindrical, short pedicellate, non-amyloid. Ascospores $10-25 \times 7-12 \mu \mathrm{m}(\bar{x}=21.5 \times$ $9.5 \mu \mathrm{m}, \mathrm{n}=40$ ), uniseriate, 1-celled, ovoid, hyaline to pinkish, aseptate, with 1-2 guttules. Asexual morph: Undetermined (description modified from Iturriaga \& Pfister 2006).

Material examined -CHINA, Sky tree, Menla County, Yunnan Province, 400m alt., on soil near the vegetation of Dipterocarpaceae 7 July 2014, Xiaobin Liu 394 (HKAS87041).THAILAND, Prachuapkhirikhan Province, Pong Prasat, Bang Saphan District, July 30 2015, A. R. Bandara (MFLU 15-2359).

Notes - Cookeina tricholoma and $C$. korfii are distinct from other species in the genus in having both spines and hairs, and hyaline to pink ascospores. However they differ from ascospore ornamentation. Boedijn (1933) and Meléndez-Howell et al. (2003) indicates that the ascospore of C. tricholoma, bear parallel longitudinal, low ridges that form the ascospore ornamentation and slightly spinose surface. However the spore ornamentation is only seen in mature spores (Iturriaga \& Pfister 2006).

Cookeina venezuelae (Berk. \& M.A. Curtis) Le Gal, Discomyc. Madagascar (Paris): 239 (1953) Facesoffungi number: FoF 02678

Saprobic on dead stems. Sexual morph: Apothecia up to $30 \mathrm{~mm}$ diam. when fresh, up to 20 mm diam. when dry, arising singly to gregarious, sessile to subsessile, deep or shallowly cupulate, 

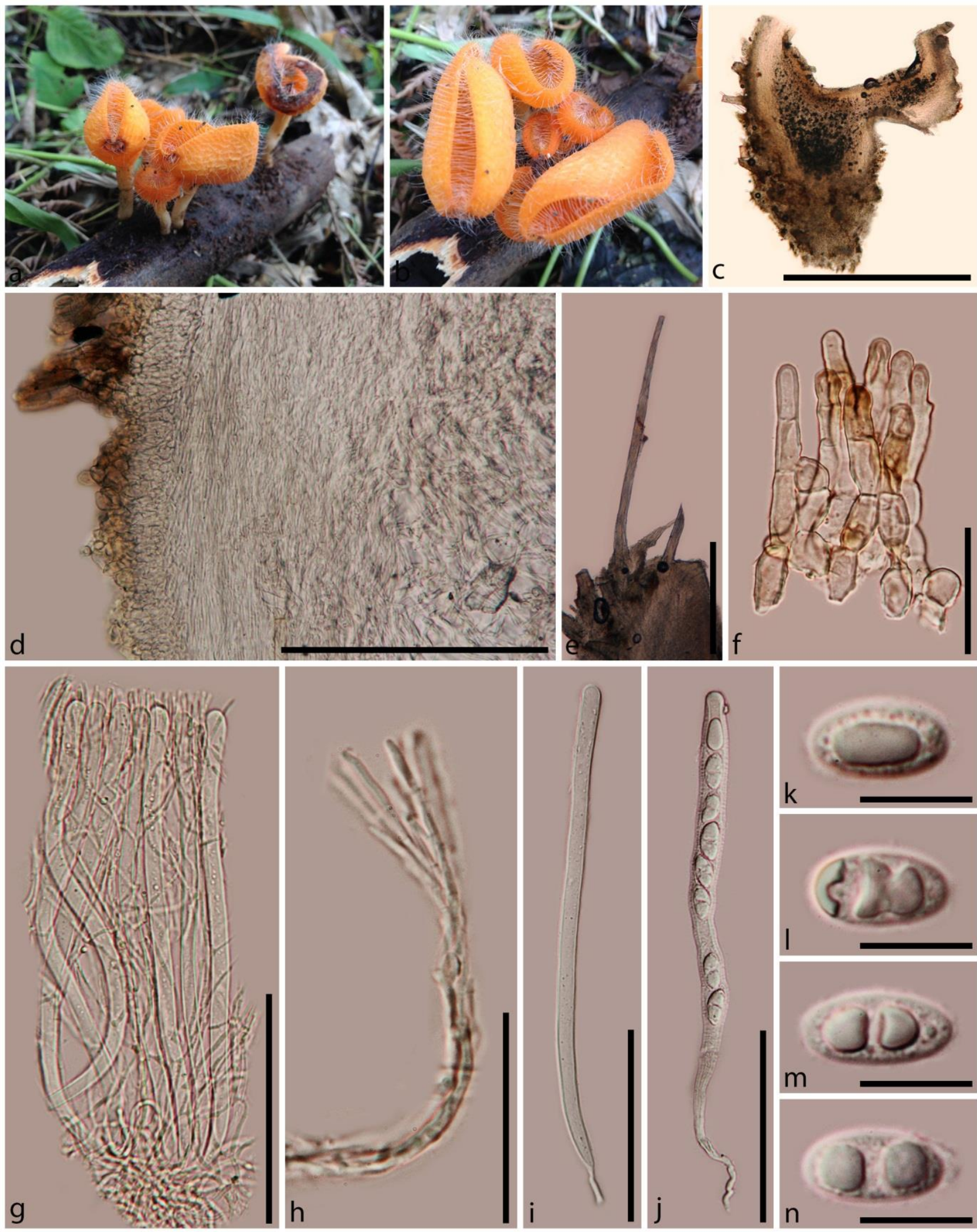

Fig. 5 - Cookeina tricholoma. a Apothecia on wood, b Apothecia, c Cross section of an apothecium, d Close up of excipulum, e Cylindric, pointed spines, f Cylindric, short hairs, g Asci and paraphyses in hymenium layer, $\mathrm{h}$ Septate paraphyses, $\mathrm{i}, \mathrm{j}$ long pedicellate asci, $\mathrm{k}-\mathrm{n}$ Ovoid ascospores. - Scale bars $\mathrm{c}=2 \mathrm{~cm}, \mathrm{~d}=200 \mu \mathrm{m}, \mathrm{e}=600 \mu \mathrm{m}, \mathrm{f}=40 \mu \mathrm{m}, \mathrm{g}=100 \mu \mathrm{m}, \mathrm{h}=40 \mu \mathrm{m}, \mathrm{i}, \mathrm{j}$ $=80 \mu \mathrm{m}, \mathrm{k}-\mathrm{n}=10 \mu \mathrm{m}$.

salmon to rose pink when fresh. Receptacle concolorous or slightly lighter than the disc. Disc glabrous, salmon to rose pinkish when fresh, cream colored to light brown when dry. Hairs on flanks and margins, cylindrical, aseptate, undifferentiated hyphal tip. Stipe $1-3 \times 2 \mathrm{~mm}$ present or 
lacking, when present central or slightly eccentric, obconic, concolorous to receptacle. Ectal excipulum 66-88 $\mu \mathrm{m}$, two layers, outer ectal excipulum composed of large, thick-walled cells of textura prismatica to globulosa and inner ectal excipulum composed of gelatinized thick hyphae (1.5-4 $\mu \mathrm{m}$ in diam.), parallel to one another, perpendicular to the receptacle. Medullary excipulum 80-90 $\mu \mathrm{m}$, composed of hyaline cells of textura porrecta, hyphae parallel to one another and to the receptacle. Subhymenium composed of textura intricata to porrecta. Paraphyses $2-5 \mu \mathrm{m}$ wide, numerous, filiform, septate, highly branched and slightly swollen at the apex (up to $5 \mu \mathrm{m}$ diam.), forming the epithecium. Asci 275-550 × 10-30 $\mu \mathrm{m}$, unitunicate, operculate, cylindrical, round to slightly tapered at the base. Ascospores $24-43 \times 9-18 \mu \mathrm{m}$, uniseriate, elliptic, fusoid, pale yellow with two large central guttules, with few longitudinal ribs and many transverse interconnected ribs on ascospore surface, aseptate. Asexual morph: Undetermined (description modified from Iturriaga $\&$ Pfister 2006).

Notes - Cookeina venezuelae similar to C. colensoi in having gelatinous material in the inner ectal excipulum and hairless apothecia with stipes. However the ascospores of $C$. colensoi are smooth and apiculate, whereas those in $C$. venezuelae are non-apiculate and distinctively marked with longitudinal ribs (Le Gal 1953).

\section{Discussion}

In the present study we discuss the taxonomy and phylogeny of the genus Cookeina, and introduce a new species Cookeina garethjonesii. We illustrate collections of $C$. indica, $C$. sulcipes and C. tricholoma from Thailand and China. Descriptions of all Cookeina species are provided from the literature and an updated phylogenetic tree is shown to illustrate the placement of taxa. In the phylogenetic tree based on ITS sequence data (Fig. 1), there are four major clades in the genus. Clade 1 includes $C$. sulcipes, $C$. garethjonesii and $C$. speciosa. All species in Clade 1 have long, centrally stipitate apothecia with short hair like projections (rudimentary hairs). Clade 2 comprises C. colensoi, $C$. venezuelae and $C$. insititia that have a gelatinized ectal excipulum in both mature and immature specimens. Cookeina speciosa also have gelatinized ectal excipular layer, but this is apparent in some young fertile specimens (Iturriaga \& Pfister 2006). All species in Clade 3 ( $C$. korfii, C. sinensis, C. tricholoma) have both spines and hairs on their apothecia. Cookeina indica and $C$. cremeirosea make up Clade 4 and they are characterized by substipitate to sessile apothecia and lack hairs on the receptacle. These results are similar to those of Weinstein et al. (2002), Iturriaga \& Pfister (2006), Iturriaga et al. (2015) and Kropp (2016).

Molecular data is not available for $C$. globosa and $C$. colensoiopsis. However, their morphologies are similar to $C$. speciosa in having hymenial setae or hairs, long stipitate apothecia with hair-like projections (Iturriaga \& Pfister 2006). Hence phylogenetically C. globosa and $C$. colensoiopsis should be members of Clade 1 close to $C$. speciosa.

\section{Acknowledgements}

Samantha C. Karunarathna, A. R. Bandara and Xiaobin Liu are thanked for collecting these specimens. This study was supported by the National Natural Science Foundation of China (No. 31360015) and the CAS/SAFEA International Partnership Program for Creative Research Teams, and the Knowledge Innovation Program of the Chinese Academy of Sciences (No. KSCX2-EW-Z9 KIB2016002). Anusha H. Ekanayaka is grateful to (Late) Mr. W. Ekanayaka, Mrs. C. Ekanayaka and Mr. A. Surasinghe for their valuable support and encouragement.

\section{References}

Bi Z, Zheng G, Li T. 1993 - The Macrofungus Flora of China's Guangdong Province 731 p. Hong Kong, Chinese University Press.

Boedijn KR. 1933 - The genera Phillipsia and Cookeina in Netherlands India. Bulletin du Jardin Botanique de Buitenzorg 13, 57-76. 
Douanla-Meli C, Langer E. 2005 - Notes on Discomycetes (Helotiales, Pezizales): new species and new records from Cameroon. Mycotaxon 92, 223-237.

Denison WC. 1967 - Central American Pezizales. II. The genus Cookeina. Mycologia 59, 306317.

FigTree version 1.4.0. Available from: http://tree.bio.ed.ac.uk/software/figtree/. (accessed December 2015).

Hall T. 2004 - BioEdit. Ibis Therapeutics, Carlsbad, CA, 92008, USA. Available from: http://www.mbio.ncsu.edu/ BioEdit/bioedit.html (accessed December 2015).

Hanlin RT. 1998 - Combined keys to illustrated genera of Ascomycetes Volumes I \& II. The American Phytopathological Society. 107 pp.

Index Fungorum (2016) Available from: http://www.indexfungorum.org/Names/Names.asp. (accessed June 2016).

Iturriaga T, Pfister DH. 2006 - A monograph of the genus Cookeina (Ascomycota, Pezizales, Sarcoscyphaceae). Mycotaxon 95, 137e180.

Iturriaga T, Xu F, Pfister DH. 2015 - Cookeina korfii, a new species hidden in Cookeina tricholoma. Ascomycete.org 7(6), 331-335.

Jayasiri SC, Hyde KD, Ariyawansa HA, Bhat J et al. 2015 - The Faces of Fungi database: fungal names linked with morphology, phylogeny and human impacts. Fungal Diversity 74, 3-18.

Kropp BR. 2016 - Cookeina cremeirosea, a new species of cup fungus from the South Pacific. Mycoscience, http://dx.doi.org/10.1016/j.myc.2016.09.003.

Le Gal M. 1953 - Les Discomycètes de Madagascar. Prodr. Flore Mycol. Madagascar 4, 1-465.

Meléndez-Howell LM, Mascarell G, Bellemère A. 2003 - Etudes ultrastructurales dans le genre Cookeina (Ascomycetes, Pezizales, Sarcoscyphaceae). Mycotaxon 87, 53-80.

Miller MA, Holder MT, Vos R, Midford PE, Liebowitz T, Chan L, Hoover P, Warnow T. 2009 The CIPRES Portals. Available from: http://www.phylo.org/sub_sections/portal. (accessed December 2015).

Nylander JAA. 2004 - MrModeltest 2.0. Program distributed by the author. Evolutionary Biology Centre, Uppsala University.

Patil A, Patil MS, Dangat BT. 2012 - Cookeina Sinensis from India. Mycosphere 3(5), 603-605.

Pfister DH. 1973 - Notes on Caribean discomycetes IV. Cookeina venezuelae, C. colensoi and the genus Boedijnopeziza. Phytologia 27, 55-62.

Pfister DH, Kaushal R. 1984 - Cookeina indica, a new species from India with a key to the species of Cookeina. Mycotaxon 20, 117-121.

Rifai MA. 1968 - The Australasian Pezizales in the herbarium of the Royal Botanic Gardens, Kew. Verh Kon Ned Akad Wetensch, Afd Natuurk, Tweede Sect 57, 1-295.

Seaver FJ. 1913 - Some tropical cup- fungi. Mycologia 5, 185-193.

Stamatakis A. 2006 - RAxML-VI-HPC: maximum likelihood-based phylogenetic analyses with thousands of taxa and mixed models. Bioinformatics 22, 2688-2690.

Swofford DL. 2003 - PAUP*: phylogenetic analysis using parsimony (*and other methods), version 4. Sinauer Associates, Sunderland, Massachusetts.

Wang Z. 1997 - Taxonomy of Cookeina in China. Mycotaxon 62, 289-298.

Weinstein RN, Pfister DH, Iturriaga T. 2002 - A phylogenetic study of the genus Cookeina. Mycologia 94, 673-682.

White TJ, Bruns T, Lee S, Taylor J. 1990 - Amplification and directmsequencing of fungal ribosomal RNA genes for phylogenetics. In: Innis MA, Gelfand DH, Sninsky JJ, White TJ (eds), PCR protocols a guide to methods and applications. Academic Press, Inc., New York, pp 315-322. 